\title{
IDENTIFICATION OF POLYMORPHISM OF FSH BETA-SUBUNIT GENE AS SPERM QUALITY MARKER IN BALI CATTLE USING PCR-RFLP
}

\author{
A.B.L. Ishak ${ }^{1,4}$, C. Sumantri ${ }^{2}$, R. R. Noor ${ }^{2}$ and I. Arifiantini ${ }^{3}$ \\ ${ }^{1}$ Graduate School, Bogor Agricultural University, \\ Jl. Agatis, Darmaga Campus, Bogor - Indonesia \\ ${ }^{2}$ Faculty of Animal Science, Bogor Agricultural University, \\ Jl Agatis, Darmaga Campus, Bogor - Indonesia. \\ ${ }^{3}$ Faculty of Veterinary Medicine, Bogor Agricultural University, \\ Darmaga Campus 16680, Bogor - Indonesia \\ ${ }^{4}$ Assesment Institute for Agricultural Technology, South Sulawesi, \\ Jl. Perintis Kemerdekaan Km 17 Makassar, South Sulawesi - Indonesia \\ Coresponding E-mail : lompengengishak_genetika@yahoo.co.id
}

Received September 30, 2011; Accepted Nopember 19, 2011

\begin{abstract}
ABSTRAK
Penelitian dilakukan untuk mengidentifikasi keragaman gen FSH beta-subunit dengan metode PCR-RFLP sebagai penanda kualitas sperma pada sapi Bali. Pengambilan sampel darah untuk ekstraksi DNA dari berbagai populasi sebanyak 470 sampel dan 127 sampel yang berasal dari Balai Nasional Inseminasi Buatan dan Balai Inseminasi Buatan Regional beserta data sperma. Frekuensi alel pada sapi Bali adalah alel A $(0,000)$ dan alel B $(1,000)$. Tidak ditemukannya alel A menunjukkan gen FSH betasubunit pada sapi Bali bersifat monomorfik. Hasil yang berbeda pada sapi Brahman, FH, Simmental dan Limousin yang bersifat polimorfik dengan adanya alel A dan B. Heterozigositas pengamatan tertinggi pada sapi Limousin $(0,318)$ dan heterozigositas harapan tertinggi pada sapi Simmental $(0,420)$. Nilai chi-square tidak berpengaruh nyata pada sapi Bali dan Simmental, namun pada sapi Brahman, FH dan Limousin berpengaruh nyata. Pada bangsa sapi yang dianalisis persentase abnormalitas sperma lebih tinggi ditemukan pada sapi Simmental, Limousin, Brahman dibandingkan pada sapi Bali dan FH. Persentase abnormalitas sperma tipe abaxial lebih tinggi ditemukan pada sapi Brahman, Simmental dibandingkan pada sapi FH. Dari semua tipe abnormalitas sperma, persentase tipe abaxial dan microcephalus paling tinggi.
\end{abstract}

Kata kunci : Gen FSH beta-subunit, polimorfisme, abnormalitas sperma

\begin{abstract}
The aim of study was to identify the association of FSH beta-subunit gene polymorphisms with sperm quality traits. A total of 470 samples of normal mature bull from several breeds were used for population study and 127 bulls from National and Regional AI centre of Indonesia for association study. To amplify, a PCR-RFLP method was used and digested with Pst 1 restriction enzyme. The allele frequency of the A and B in Bali cattle were (0.000) and (1.000), respectively. The absence of other allele A suggested that the Bali cattle was monomorphic, while Brahman, FH, Simmental and Limousine were polymorphic. The highest observed heterozygosity were found in Limousine $(0.318)$ and the highest expected heterozygosity were in Simmental (0.420). The higher incident of percentage of sperm abnormalities were found in Simmental, Limousin, Brahman compared to Bali and FH. Among all types of sperm abnormalities, the abaxial and microcephalus were found in highest number.
\end{abstract}

Key words : FSH beta-subunit gene, polymorphism, sperm abnormalities

\section{INTRODUCTION}

Follicle stimulating hormone (FSH) is a glycoprotein hormone expressed in the pituitary, and it is responsible for regulating reproduction in mammals (McLahlan and Meachem, 2003; Otha et al. 2007). In males, FSH incombination with testosterone is the most important tropic hormone 
regulating Sertoli cell function, requires for the initiation and maintenance of the quality and quantity sperm in spermatogenesis processes. Follicle stimulating hormone (FSH) acts on the germinal cells in the seminiferous tubules of the testis and is responsible for spermatogenesis up to the secondary spermatocyte stage, and androgens from the testis support the final stages of spermatogenesis.

The genetic factors influence on production and sperm quality have been reported by several studies (Kim et al., 1988; Fries, 1989). Dai et al. (2009) and Dai et al. (2011) examined the gene polymorphism FSH beta-sub unit of production and sperm quality in Simmental, Charolais and Limousin. Some researchers also associate the diversity of FSH beta-sub unit genes with litter size in sow (Yaofeng et al., 1998; Li et al., 2000; Li et al., 2008; Liu et al., 2009), sperm quality in boar (Wimmer et al., 2005; Lin et al., 2006), litter size in ewes (Xiaopeng et al., 2010; Zhang et al., 2011) and equine sperm quality (Samper, 2010). FSH beta-sub unit gene specific unit is located on chromosome 15 that comprises two introns and three exons with a length of $6601 \mathrm{bp}$ (Kim et al., 1988; Fries, 1989; Hediger et al., 1991). Variants of this gene was three alleles, namely A, B, and C. Dai et al. (2009) found 9 SNPs mutations, i.e. 4 mutations in promoter section ('5 URR), 3 in intron 2, and 2 in exon 3. Polymorphism of FSH beta-sub unit gene in exon 3 on the study significantly influenced the fresh and frozen semen quality. The $\mathrm{AA}$ and $\mathrm{AB}$ genotypes showed better quality of fresh as well as in frozen semen when compared to the BC. Based on the previous study in Bos taurus and Bos indicus, this research aimed to investigate the polymorphisms of FSH beta-sub unit gene as marker of sperm quality in Bali cattle (Bos javanicus).

\section{MATERIALS AND METHODS}

\section{Sources of Animal and Data Collection}

A total of 470 heads of normal mature bulls (225 Bali, 69 Brahman, 92 FH, 44 Limousin and 40 Simmental) for population studied. While, for association studied were used normal mature bulls from National and Regional AI centre of Indonesia (24 Bali, 6 Brahman, 13 FH, 44 Limousin and 40 Simmental).

\section{Isolation of Genomic DNA}

Blood samples were collected from each bull in 10-ml non anticoagulan polypropylene tubes. Blood samples then were mixed with $96 \%$ ethanol. Genomic DNA was isolated by the phenol-chloroform extraction method (Sambrook et al., 1998: Andreas et al., 2010) and then were dissolved in TE buffer (10mM Tris-HCl, pH 8.0; $1 \mathrm{mM}$ EDTA). Genomic DNA was stored at -20 ${ }^{\circ} \mathrm{C}$ until amplification with polymerase chain reaction (PCR).

\section{PCR Amplification and RLFP Analysis}

The amplification of PCR was carried out using specific primer (Dai et al., 2009) for part intron 2 and complete coding of exon 3 (313 bp) (Table 1). The PCR was performed in a final volume of $25 \mu \mathrm{l}$ for each reaction containing $2 \mu \mathrm{l}$ DNA templates, $0.2 \mu \mathrm{l}$ primer, $0.2 \mu \mathrm{l}$ dNTPs, 0.1 $\mu \mathrm{l}$ Taq polymerase, $1 \mu \mathrm{MgCl}, 2.5 \mu \mathrm{l} 1 \mathrm{X}$ reaction buffer and $18.1 \mu$ lilution of sterile water. The reaction mixture was subjected to an initial $5 \mathrm{~min}$ of denaturation $95{ }^{\circ} \mathrm{C}$, followed 35 cycles of denaturation at $95{ }^{\circ} \mathrm{C}$ for $30 \mathrm{sec}$, annealing $30 \mathrm{sec}$ at $63{ }^{\circ} \mathrm{C}$, extention $1 \mathrm{~min}$ at $72{ }^{\circ} \mathrm{C}$ and final extention $5 \mathrm{~min}$ at $72{ }^{\circ} \mathrm{C}$. Amplicons were visualized by electrophoresis in $1.5 \%$ agarose gels containing $500 \mathrm{ng} / \mathrm{ml}$ of ethidium bromide in $1 \times$ TAE buffer with a 100-bp ladder as the molecular weight marker for confirmation of the length of the PCR products. For digestion by using enzyme and determination of RFLP, $7 \mu$ l of PCR product was added to $1 \mu \mathrm{l}$ e Pst 1 enzyme and $2 \mu \mathrm{l}$ buffer $10 \mathrm{X}$ with final volume $10 \mu \mathrm{l}$. The PCR products of FSH beta-sub unit gene digested at $37^{\circ} \mathrm{C}$ overnight by Pst 1 enzyme. The digestion products were separated by horizontal electrophoresis (85 volts, $50 \mathrm{~min}$ ) in $2 \%$ agarose gels in $1 \times \mathrm{TBE}$ and $10 \%$ ethidium bromide.

\section{Semen Preparation}

Methods of fresh semen collections and smears preparations was according to Arifiantini et al. (2010) and Bhakat et al. (2011), and were

Table 1. Primer Sequence Used in PCR

\begin{tabular}{llccc}
\hline Primer & Sequence & PCR Product & Annealing & Reference \\
\hline Forward & F: 5CTTCCAGACTACTGTAACTCATC`3 & $313 \mathrm{bp}$ & 63 & Dai et al. (2009) \\
Riversed & R: 5 'GTAGGCAGTCAAAGCATCCG‘3 & & & \\
\hline
\end{tabular}


performed from bull in AI centers. The samples were then delivered to the research Animal Genetic and Molecular Laboratory in Bogor Agricultural University. Sample collections were performed based on the standard protocol: a drop of semen was placed on the a glass slide, mixed with four drops of physiologic saline, homogenized by using a stick, and smeared on different glass slides. Smeared semen samples were air dried coded according to the bull ID, and packed in a glass slides box. Smeared samples were stained with carbolfuchsin-eosin according to the method described by Williams in 1920 and modified by Lagerlof in 1934 (Kavak et al., 2004). Steps in Williams staining protocol were as follow: The air-dried, thin smears of fresh semen on glass slides from AI centers were fixed in flame, washed with absolute alcohol for 4 minutes, and air dried. Then, the smears were treated with $0.5 \%$ chloramines solution for 2 minutes until the mucous disappeared and the smears looked fairly clear. The smears were washed in distilled water, rinsed in $95 \%$ alcohol, and stained with Williams for 8-10 minutes. Finally, the smears were washed in running water and allowed to dry.

\section{Data analysis.}

PCR-RFLP data were analyzed by calculating allele and genotype frequencies (Nei and Kumar, 2000). The allele and genotype frequencies were calculated by the following formulas :

$X=\frac{\left(2 \mathrm{n}_{i i}+\sum n_{i j}\right)}{2 \mathrm{n}}$

$\mathrm{x}=$ allele frequencies

$\mathrm{n}_{i j}=$ Number of genotype $A_{i} A_{j}$

$\mathrm{n}_{i i}=$ Total of genotype $A_{i} A_{i}$

$\mathrm{n}=$ Total sample

$\hat{h}=2 \mathrm{n}-\frac{\left(1-\sum x_{i}^{2}\right)}{2 \mathrm{n}}$

$\mathrm{x}_{i}=$ allele frequencies

$n=$ Total sample

$\hat{h}=$ heterozigosity

\section{Hardy-Weinberg equilibrium}

Hardy-Weinberg equilibrium was tested by the $x^{2}$ (Chi-square) (Noor, 2008).

$\chi^{2}=\frac{\sum(O-E)^{2}}{E}$

$\chi 2=$ Hardy-Weinberg equilibrium test
$\mathrm{O}=$ observed number of genotype A11

$\mathrm{E}=$ expected number of genotype A11

Degree of freedom (df) was according to Allendorf and Luikart (2007) :

$\mathrm{df}=($ Number of genotype-i) $-($ Number of allele $-\mathrm{j}$ )

\section{Sperm Abnormalities}

The sperm were counted on each smeared using a light microscope at $400 \mathrm{X}$ magnification (Olympus CH 20). Sperm morphology was examined and all types of abnormalities were recorded and classified. The classification sperm abnormalities was based on Bart and Oko (1989), Chenoweth (2005) and Arifiantini et al. (2010) such as : abaxial, macrochepalus, microchepalus, round head and knobbed acrosome defect. Sperm abnormalities were calculated from the type of abnormality in each field of view or 500 cells. Sperm abnormalities $=$ $\frac{\text { number of type sperm abnormalities }}{500 \mathrm{cell}} \times 100$

\section{RESULTS AND DISCUSSIONS}

\section{Amplification of FSH beta-sub unit Gene}

The amplicon of FSH beta-subunit was 313 bp in lenght, in which this result was consistent with Dai et al. (2009). FSH beta-sub unit gene was located in chromosomes 15th with 3 exons and 2 introns (Kim et al., 1988; Xiao-peng et al., 2010). The nucleotide sequnces of FSH sub-beta unit gene were 6610 base pair in length (GenBank No : M83753).

In this research, it has been amplified part of intron 2 and the complete coding region of exon 3 (313 bp). The amplification fragment of FSH beta-sub unit gene carried on GeneAmp ${ }^{\circledR}$ PCR System 9700 (Applied Biosystem) is shown in Figure 1.

\section{Genotype and Allele Frequencies}

The PCR product that has been digested by Pst 1 enzyme incubated for 14 hours at $37{ }^{\circ} \mathrm{C}$ resulted in 3 fragments. Genotype data of FSH beta-sub unit gene showed 313 bp for genotype BB, 202 bp and 99 bp for genotype AA, $313 \mathrm{bp}$, 202 bp and 99 bp for $A B$ genotype. Visualization of RFLP result is shown in Figure 2.

Results of FSH beta-sub unit gene analysis showed that only B allele and BB genotype was found in Bali cattle. The absence of other alleles 
suggested that Bali was monomorphic. This result was different from Brahman (Bos indicus), FH, Simmental and Limousine (Bos taurus) showing polymorphic. There was variation of alleles A and $\mathrm{B}$ as well as genotype variation, those were AA, $\mathrm{AB}$ and $\mathrm{BB}$. The highest frequency of allele $\mathrm{A}$ was found in $\mathrm{FH}(0.891)$ and the lowest one in Bali cattle (0000). The highest allele B was found in Bali (1.000) and the lowest one in Brahman cattle (0.174). These findings were similar to those previous reported in Germany FH cattle and Gelbvieh cattle (Schlee et al., 1994), frequency of allele A was 0.000 and B was 1.000. Schlee et al. (1994) found the frequencies of allele A and B in Simmental were 0.831 and 0.147 , respectively; in Limmousin were 0.910 and 0.431 , respectively. The allele and genotype frequency of each breed presented in Table 2.

\section{Sequences Alignment of the FSH Beta-sub Unit Alleles}

The result of PCR product sequences showed mutation. Sequences based on GenBank access number M83753, the gonotype AA at position 237 and 238 nucleotides were $\mathrm{CA}$, but the $\mathrm{BB}$ genotype was TG (Figure 3).

\section{Association polymorphism FSH beta-sub unit gene with sperm abnormalities}

Sperm abnormalities have long been associated with male infertility and sterility in most species studied. These abnormalities vary from morphological defects that are evident upon clinical examination, to those, which are more subtly defective. In general, sperm structure can play a substantial role in both fertilization and pregnancy outcome (Chenoweth, 2005). Eventhough the heritability of bull fertility is generally considered to be low, certain aspects of bull fertility, including sperm morphological abnormalities are under genetic control. Sperm abnormalities according to Chenoweth (2005) and

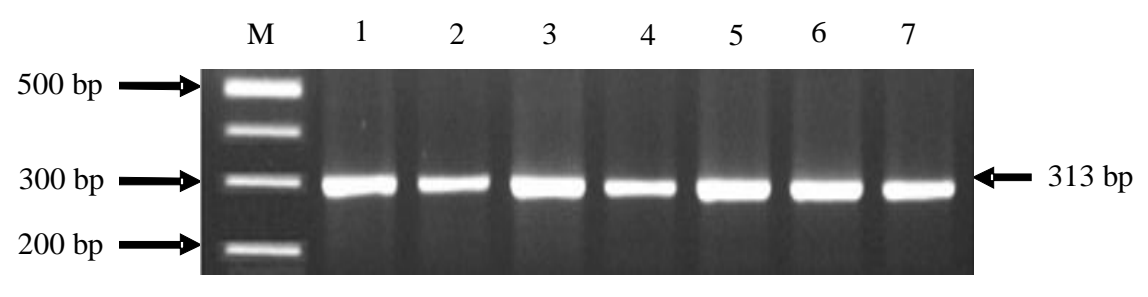

Figure 1. Amplification of FSH Beta-subunit Gene

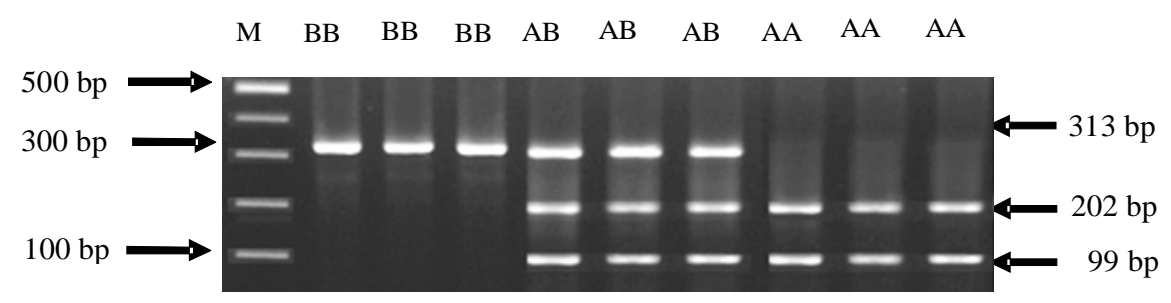

Figure 2. Genotyping of FSH Beta-subunit Gene with Pst1 Enzyme

Table 2. Allele and genotype Frequencies of FSH Beta-subunit Gene

\begin{tabular}{|c|c|c|c|c|c|c|c|}
\hline \multirow{2}{*}{ Breed } & \multirow{2}{*}{$\begin{array}{c}\text { Allele } \\
\text { A }\end{array}$} & \multicolumn{4}{|c|}{ Genotype } & \multirow{2}{*}{$X^{2}$} & \multirow{2}{*}{$P I C$} \\
\hline & & B & AA & $\mathrm{AB}$ & $\mathrm{BB}$ & & \\
\hline Bali & 0.000 & 1.000 & (0) 0.000 & (0) 0.000 & 1.000 (225 ) & - & - \\
\hline Brahman & 0.174 & 0.826 & (6) 0.087 & 0.174 & 0.739 (51) & $10.75 *$ & 0.246 \\
\hline FH & 0.891 & 0.109 & 0.880 & (2) 0.022 & (9) 0.098 & $72.51 *$ & 0.175 \\
\hline Simental & 0.700 & 0.300 & 0.600 & (8) 0.200 & 0.200 & $10.97 *$ & 0.332 \\
\hline Limosin & 0.818 & 0.182 & 0.659 & 0.318 & (1) 0.023 & 0.212 & 0.253 \\
\hline
\end{tabular}

Note $:()=$ number of sample, ${ }^{*}=$ significant $(\mathrm{P}<0.05), \mathrm{PIC}=$ Polymorphism Information Content 


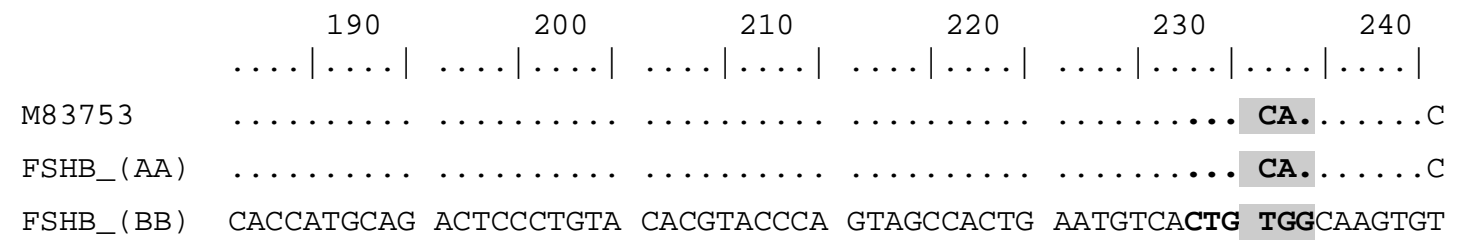

Figure 3. The Position of Polymorphic FSH Beta-sub Unit Gene

Table 3. Persentage of Sperm Abnormalities in Different Breed

\begin{tabular}{lcrrrrr}
\hline \multirow{2}{*}{ Breed } & Genotype & Abaxial & $\begin{array}{c}\text { Macro } \\
\text { chepalus }\end{array}$ & $\begin{array}{c}\text { Micro } \\
\text { chepalus }\end{array}$ & Round head & $\begin{array}{r}\text { Knobbed } \\
\text { acrosome } \\
\text { defect }\end{array}$ \\
\hline Bali & BB (24) & 0.34 & 0.17 & 0.17 & 0 & 0.37 \\
Brahman & AA (3) & 0.09 & 0 & 0.02 & 0 & 0.06 \\
& AB (2) & 0.01 & 0 & 0 & 0 & 0 \\
Holstein Frisian & BB (3) & 0.01 & 0.01 & 0.01 & 0 & 0 \\
\multirow{5}{*}{ Simmental } & AA (9) & 0.03 & 0.03 & 0.08 & 0.05 & 0.09 \\
& BB (4) & 0.05 & 0 & 0.03 & 0 & 0.10 \\
\multirow{3}{*}{ Limosin } & AA (18) & 0.72 & 0.50 & 0.50 & 0.21 & 0.22 \\
& AB (9) & 0.14 & 0.07 & 0.22 & 0.07 & 0 \\
& BB (9) & 0 & 0.22 & 0.29 & 0.65 & 0 \\
& AA (10) & 0 & 0.1 & 0.21 & 0.21 & 0.20 \\
& AB (9) & 0.31 & 0.05 & 0.26 & 0.10 & 0 \\
\hline
\end{tabular}

Freneau et al. (2010) was divided into major (15 type) and minor abnormality (16 type), where abnormality was caused by genetic factors ie. abaxial (abormalitas on the tail), round head, microchepalus, macrochepalus, knobbed acrosome defect (abnormalities in the head). Abaxial is a type of sperm abnormality whereas the implantation fossa of the tail is off-center. Variable size is a term to describe sperm possessing head abnormalities which are bigger (macrocephalus) or smaller (microcephalus) than the normal size. Knobbed acrosome defect occurs in the acrosome region of sperm; the apex of the acrosome is flatte or inden ( Table 3).

Among all types of sperm abnormalities, the microchepalus and abaxial were found in highest number, especially in Brahman bull, in contras the round head was found in low number in Bali bull cattle. While in FH semen, knobbed acrosome defect and microchepalus were found in highest number. This research demonstrated that the Simmental and Limousin have a highest number of microchephalus and round head. Arifiantini et al. (2010) reported the sperm abnormalities from
14 AI centre in Indonesia, it was found that the Simmental, Limousine and Brahman cattle have a high number of primary sperm abnormalities which were $4.8 \%, 3.6 \%, 2.6 \%$ respectively, compare to Bali only was $1.8 \%$, even so, its classified as low primary sperm abnormality. Classification as high primary sperm abnormality if the percentage is larger than 10.1-15 and very high if larger than $>15 \%$. Purwantara et al. (2010) found 1.00 to $8.40 \%$ primary sperm abnormality mostly pearshaped of FH bull from 20 samples collected from three different AI centers.

In this study the primary sperm abnormality such as the abaxial and microchepalus were found mostly in AA and BB genotypes and only abaxial was found the highest number in $A B$ genotype (Figure 4).

\section{CONCLUSION}

The FSH beta-subunit gene in Bali cattle was monomorphic, in contrast to Brahman, FH, Limmousin and Simmental, in which were 


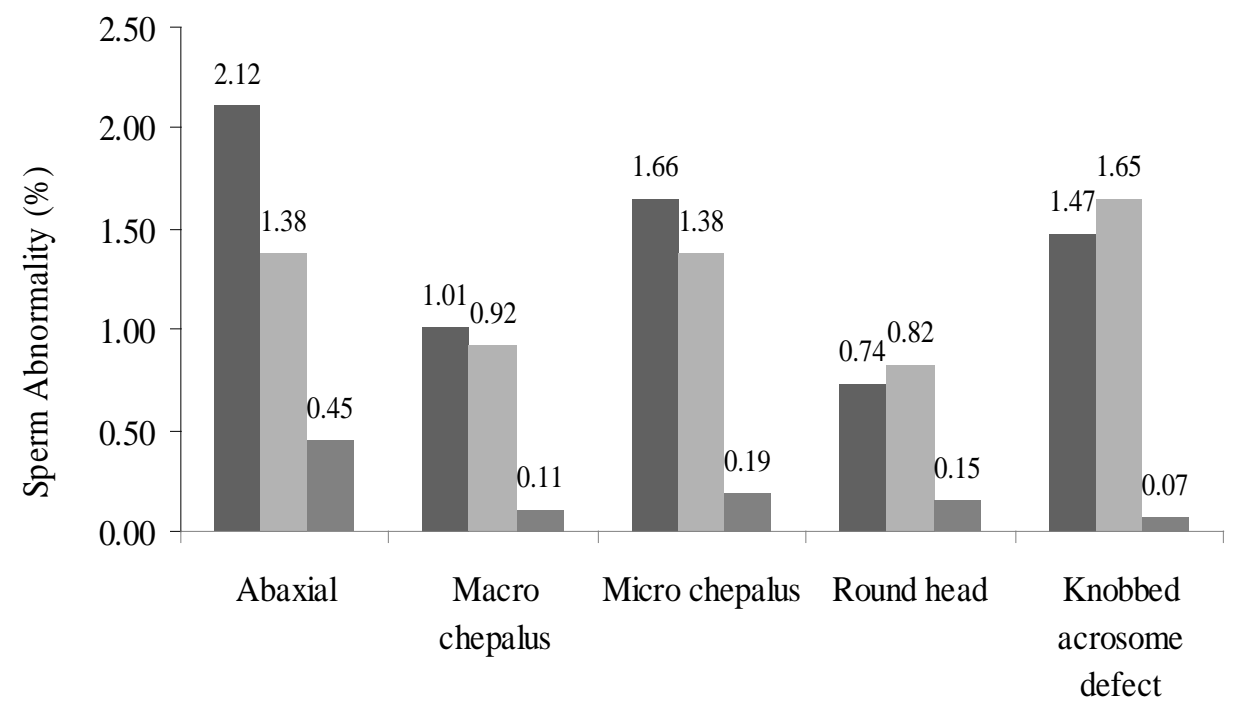

Figure 4. Type of Sperm Abnormalities Type of Bull Semen in Different Genotype

: $\mathrm{AA}, \quad: \mathrm{BB}, \quad$ : $\mathrm{AB}$

polymorphyc with PCR-RFLP. In association to polymorphisms of FSH beta-sub unit gene in different genotypes with the percentage of the highest sperm abnormality, it was found in BB and AA genotypes.

\section{ACKNOWLEDGMENT}

The authors acknowledge the head of AI centers Lembang Bandung, head of AI centers South Sulawesi, South East Sulawesi, Bali, NTT, NTB for providing semen and blood samples.

\section{REFERENCES}

Allendorf, F.W. and G. Luikart. 2007. Conservation and the Genetic of Population. Blackwell Publishing.

Andreas, E., C. Sumantri, A. Farajalah and A. Anggraeni. 2010. Identification of $\mathrm{GH} \mid \mathrm{A} l u 1$ and GHR $\mid \mathrm{A} l u 1$ genes polymorphism in Indonesian buffalo. J. Indonesian Trop. Anim. Agric 35:215-221

Arifiantini, R.I., B. Purwantara and M. Riyadhi. 2010. Occurrence of sperm abnormality of beef cattle at several Artificial Insemination Centers in Indonesia. Anim. Prod. 12:44-49

Barth, A.D and R.J. Oko. 1989. Abnormal Morphology of Bovine Sperm. Iowa: Iowa State University Press.
Bhakat, M., T. K. Mohanty, V. S. Raina, A. K. Gupta, P. K. Pangkaj, M. K. Mahapatra and M. Shakar, 2011. Study on suitable semen additives incorporation into the extender stored at refrigerated temperature. AsianAust. J. Anim. Sci. 10:1348-1357

Chenoweth, P.J. 2005. Genetic sperm defect. Theriogenology. 64:457-468

Dai, L., Z. Zhihui, R. Zhao, S. Xia, H. Jiang, X. Yue, X. Li, G. Yan, J. Liu and J. Zhang. 2009. Effects of novel single nucleotide polymorphisms of the FSH beta-sub unit gene on semen quality and fertility in bulls. Anim. Rep. Sci. 114:14-22

Dai, L., Y. M. Zao, G.L. Zang, R.F. Zhao, H. Jiang, T.H. Ma, Y. Gao, B. Yuan, Y.L. Xu, W.Y. Yu, Z.H. Zhao and J.B. Zhang. 2011. Molecular cloning and sequence analysis of follicle-stimulating hormone beta polypeptide precursor cDNA from the bovine pituitary gland. Gen. Mol. Res. 3:1504-1513

Freneau, G.E., P.J. Chenoweth and G. Rupp. 2010. Sperm morphology of beef bulls evaluated by two different methods. Anim. Rep. Sci. 118 : 176-181

Fries, R., 1989. The gene for the $\beta$ subunit of the follicle-stimulating hormone maps to bovine chromosome 15. J. Hered. 5 : 401- 402

GeneBank, 2010. www.ncbi.nml.nih.gov. [29-101010] 
Hediger, R., S.E. Johson and D.J.S. Hetzel. 1991. Localization of the P-subunit of follicle stimulating hormone in cattle and sheep by in situ hybridization. Anim. Gen. 22:237-244

Kavak, A.N., M Lundeheim, Aidnik and S. Einarsson. 2004. Sperm morphology in Estonian and Toti breed Stallion. Act. Vet. Scan. 45:11-18.

Kim, K.E., D.F. Gordon, R.A. Maurer, 1988. Nucleotide sequence of the bovine gene for follicle-stimulating hormone beta-subunit. DNA. 7:227-233

Li, M.D., G. A. Rohre, T.H. Wise, J.J. Ford, 2000. Identification and characterization of a new allele for the beta subunit of folliclestimulating hormone in Chinese pig breeds. Anim. Gen. 31:28-30

Li, F.E., S.Q. Mei, C.Y. Deng, S.W. Jiang, B. Zou, R. Zheng, J.L. Li, D.Q. Xu, M.G. Lei and Y.Z. Xiong. 2008. Association of a microsatellite flanking $F S H B$ gene with reproductive traits and reproductive tract components in pigs. Czech J. Anim. Sci. 4:139-144

Lin, C.L., S. Ponsuksili, L, Tholen, D.G.J. Jennen, K. Schellander and K. Wimmers, 2006. Candidate gene markers for sperm quality and fertility of boar. Anim. Rep. Sci. 92:349-363

Liu, J.J., X.Q. Ran, S, Li, Y. Feng and J. F. Wang. 2009. Polymorphism in the first intron of follicle stimulating hormone beta gene in three Chinese pig breeds and two European pig breeds. Anim. Rep. Sci. 111:369-375

McLahlan, R.I., Wreford N,G., Robertson D.M and D. M. de Kretser, 1995. Hormonal Control of Spermatogenesis. Trens. Endoc. Met. 6:95-101

Nei, M and S. Kumar. 2000. Molecular Evolution and Phylogenetics. Oxford University Press.

Noor, R. R., 2008. Genetika Ternak. Edisi ke-4. Penebar Swadaya., Bogor

Ohta, T., H. Miyake, C. Miura, H. Kamei, K. Aida, T. Miura. 2007. Follicle-stimulating hormone induces spermatogenesis mediated by androgen production in Japanese eel, Anguilla japonica. Biol. Reprod. 77:970-977

Purwantara, B., R. I. Arifiantini and M. Riyadhi. 2010. Sperm morphological assesment of Holstein Frisian bull semen collected from three artificial centres in Indonesia. J. Indonesian Trop. Anim. Agric. 35:90-94

Sambrook, J., E.F. Fritsch, and T. Maniatis. 1989. Molecular Cloning. A Laboratory Manual $2^{\text {nd }}$ ed. Cold Spring Harbor Laboratory Press.

Samper J.C. 2010. Equine Breeding and Management in Artificial Insemination. Saunder Elsevier Publishing. USA.

Schlee P, J. Blush, T. Werner, E. Schallenberger, R. Graml and F. Pirchner. 1994. Nucleotide substitution in the bovine FSHB 5'-region. Gen. Mol. Mark. 3:127-128

Wimmers K, Lin C L, Tholen E, Jennen D G J, Schellander K and S. Ponsuksili, 2005. Polymorphisms in candidate genes as markers for sperm quality and boar fertility. Anim. Gen. 36:152-155

Xiaopeng A. N., H. Dan, H. Jin-Xin, L. Guang, W. Ya-Na, L. Ling, Q. Guang, W. Jiangang, S. Yu-xuan and C.Y. Bin Yun. 2010. Polymorphism of exon 2 of $\beta$ gene and its relationship with reproduction performance in two goat breeds. Agric. Sci.China. 6:889-886

Yaofeng Z, L., Ning, X. Lu, C. Gengsheng, C. Yizheng, Z. Shung, Yongfu $\mathrm{C}$ and W Changxing. 1998. FSHB subunit gene is associated with major gene controlling litter size in commercial pig breeds. Agric. Sci. China. 6:664-668

Zhang C.Y., C.J. Wu, W.B. Zeng, K.K. Huang, X. Li, J.H. Feng, D. Wang, G.H. Hua, D.Q. Xu, Q.Y. Wen and L.G. Yang, 2011. Polymorphism in exon 3 of follicle stimulating hormone beta (FSHB) subunit gene and its association with litter traits and superovulation in the goat. Small. Rum. Res. 96:53-57 